\title{
KURIKULUM 2OIB UNTUK TOTAL QUALITY EDUCATION DI INDONESIA
}

\author{
Hilmi Fauzi \\ Universitas Islam Negeri Sunan Kalijaga Yogyakarta \\ hilmifauzi10@gmail.com
}

\begin{abstract}
ABSTRAK
Isu perbaikan mutu pendidikan selalu menjadi fokus dari pelbagai pemangku kepentingan dalam pendidikan. Salah satu tujuannya adalah untuk penyiapan learning outcomes (LO) yang mempunyai daya saing dengan kompetitornya. Selain itu, juga untuk menyiapkan LO mempunyai daya sanding sehingga dapat selaras dengan zaman yang sudah memasuki era disruptif ini. Tulisan ditujukan untuk melihat bagaimana relevansi kebijakan yang diambil pemerintah untuk mengatasi permasalahan tersebut. Penulis menggunakan pendekatan manajemen dalam mengulas data yang ada. Tulisan ini menggunakan kajian pustaka dan dikuatkan dengan data dari lapangan. Hasil dari tulisan ini adalah beberapa fakta -termasuk di dalamnya fakta alternatif sebagai berikut: pemerintah melalui Kementerian Pendidikan dengan kebijakan Kurikulum 2013 dan Kemenristek Dikti melalui Kepres tentang Kerangka Kualifikasi Nasional Indonesia (KKNI) mulai melakukan usaha perbaikan pendidikan. Ada pergeseran paradigma, yang sebelumnya hanya terfokus pada pengembangan kognitif, atau sudah menuju ranah afektif dan psikomotor namun masih sangat minim, dan evaluasi yang tidak terstruktur, saat ini lebih sistematis untuk mencapai tidak hanya ranah kognitif, namun afektif, psikomotor dengan mempertimbangkan multiple intelegence. Berdasarkan fakta tersebut dapat disimpulkan bahwasannya sudah ada kesesuaian antara pendidikan dengan kebutuhan masyarakat, sehingga krisis dekadensi moral, kompetensi harapannya dapat diatasi. Pada sisi yang sama ;kurikulum 2013 tidak lain sebagai instrumen pemerintah untuk mengkontrol mutu pendidikan yang beorientasi pada jaminan mutu. Terakhir, pendidikan yang didesain pemerintah diharapkan mampu mendorong LO yang mampu mempunyai kompetensi, daya saing dan daya sanding yang selaras dengan zamannya.
\end{abstract}

Kata kunci Total, Qualiaty, Manajemen, Kurikulum, 2013.

\section{ABSTRACT}

The issue of improving the quality of education has always been the focus of the various stakeholders in education. One of the objectives is to prepare learning outcomes (LO) that have competitiveness with their competitors. In 
addition, also to prepare the LO has the power sanding so that it can be in harmony with the era that has entered this disruptive era. The paper is intended to see how the policy relevance of the government to address the problem. The author uses a management approach in reviewing existing data. This paper uses literature review and is reinforced with data from the field. The results of this paper are several facts - including the following alternative facts: the government through the Ministry of Education with the policy of Curriculum 2013 and Kemenristek Dikti through the Presidential Decree on the Indonesian National Qualification Framework (KKNI) began to make efforts to improve education. There is a paradigm shift, previously focused only on cognitive development, or already towards the affective and psychomotor spheres but still very minimal, and unstructured evaluation, is now more systematic to achieve not only the cognitive, but affective, psychomotor sphere by considering multiple intelligence. Based on these facts it can be concluded that there is a match between education and community needs, so that the crisis of moral decadence, the competence of hope can be overcome. On the same side, the 2013 curriculum is nothing but a government instrument to control the quality of education that is oriented towards quality assurance. Finally, the government-designed education is expected to encourage LOs capable of competence, competitiveness and sanding power that is in harmony with the times.

Keyword: Total, Quality, Management, Curriculum, 2013. 


\section{PENDAHULUAN}

Education sering dialih bahasakan menjadi pendidikan. Pendidikan sendiri secara bahasa mengakar pada bahasa Yunani yaitu paidagogia yang berarti "pergaulan dengan anak-anak." Pendidikan memiliki padanan kata dalam bahasa Arab yaitu tarbawy atau ta'lim (Machali dan Hidayat, 2016:25). Pendidikan yang ada di Indonesia sebagaimana dijabarkan pada Undang-undang Sistem Pendidikan Nasional No. 20 Tahun 2003 pasal 1 bahwasannya adalah usaha sadar dan terencana untuk mewujudkan suasana belajar dan proses pembelajaran agar peserta didik secara aktif mengembangkan potensi dirinya untuk memiliki kekuatan spritual keagamaan, pengendalian diri, masyarakat, bangsa dan negara (Machali dan Hidayat, 2016:27). Pendidikan menurut sudut pandang filsafat pendidikan Islam adalah untuk mempertinggi akhlak, mencapai kesejahteraan hidup di dunia dan di akhirat (Ramayulis, 2015:25). Berdasar uraian ini dapat ditarik bahwasannya pendidikan adalah sebuah usaha untuk mewujudkan manusia menjadi insan terproyeksikan (ada visi tertentu) sehingga dapat mengisi ruang-ruang/profesi tertentu sehingga dapat berhasil hidup di dunia dan akhirat.

Uraian di atas, mengarahkan pemahaman kita kepada suatu titik bahwasannya pendidikan sendiri memerlukan jalan, tariqat tertentu sehingga dapat mencapai tujuannya. Bahasa mafhum yang sering digunakan adalah pendidikan memerlukan suatu manajemen sehingga arah dan jalannya bisa terukur dan jelas. Mulai dari identifikasi, perencanaan, peningkatan partisipasi dan kerjasama sampai dengan pelaksanaan, pemeliharaan, pembinaan dan pengembangan lebih lanjut (Amtu, 2013:26). Pada akhirnya pendidikan menjadi sebuah trend yang mana mempunyai daya dampak yang besar (influence, bargaining) (Foucault, 1975:231) bagi negara, diperkuat dengan ungkapan bahwasannya proses perolehan pengetahuan dan keterampilan melalui pendidikan merupakan suatu bentuk investasi (Irianto,2011:5-7). Sehingga hadirnya pendidikan yang tersistematisasi akan membawa hasil tidak hanya yang berupa praktis, akan tetapi juga sesuatu yang bernilai investasi bagi bangsa itu sendiri.

Situasi ini bertambah pelik ketika memasuki era disuptif, bagaimana pendidikan ditantang dengan hadirnya teknologi yang sudah tak terbendung -yang mempengaruhi segala lini kehidupan-, sehingga pendidikan tidak hanya dipaksa memiliki daya saing, namun daya sanding yang selaras dengan zaman. Oleh karena itu hadirnya pendidikan sudah seharusnya dapat menelurkan Learning Output (LO) 
yang berkompeten (bermutu tinggi) sehingga bisa mengisi sendi-sendi negara menuju arah perbaikan dan pengembangan. Orientasi akhirnya adalah dapat mengukur LO itu memiliki kemampuan apa dan sejauhmana kemampuannya (Ristekdikti, 2016). Sehingga ada penngakuan oleh dunia kerja secara luas, dan dapat didayagunakan di seluruh penjuru dunia. Pada sisi realistis, setidaknya pendidikan yang ada bisa mengentaskan calon LO tersebut dari degradasi/dekadensi moral yang maa sudah menjadi penyakit akut remaja ini.

Proses menuju terciptanya LO berkompeten tersebut memerlukan suatu konsep jalan/tariqat sebagaimana disebut dalam bagian sebelumnya adalah manajemen, sehingga setidaknya dapat memastikan LO mempunyai standar minimal, yang mana acapkali kita sebut mutu. Hadirnya manajemen tersebut didesain untuk mempersiapkan strategi peningkatan mutu itu sendiri, dan relevansinya serta daya saing dengan kehidupan masa ini (Amtu, 2013:28).

Pemerintah melalui Kementrian Pendidikan Republik Indonesia memberikan upaya penjaminan mutu tersebut, salah satunya melalui jalur penerapan kurikulum 2013, yang mana disempurnakan pada tahun 2016. Permasalahan yang sering muncul adalah, apakah kurikulum 2013 sudah sesuai dan memberikan dampak positif bagi pendidikan secara umum, dan penjaminan mutu LO secara khusus. Pada tataran ini peneliti menganggap penting untuk melihat ulang, apakah usaha pemerintah dalam penjaminan mutu pendidikan melalui jalur kurikulum 2013 sudah tepat, beserta beberapa data lapangan yang relevan.

Dengan mencoba menganalisa melalui beberapa bunga-rampai tulisan yang telah ada, dan mencoba melihat langsung/observasi pada lembaga sekolah sehingga bisa megantarkankan dan memperkuat tulisan ini bagaimana daya dampak daripada kurikulum 2013 untuk pengontrolan mutu LO di Indonesia.

\section{RUMUSAN MASALAH}

Berdasarkan uraian di atas peneliti membatasi fokus permasalahan menjadi beberapa sebagai berikut:

1. Apa yang dimaksud Total Quality Management Education?

2. Sejauhmana relevansi implementasi Kurikulum 2013 dengan konsep Total Quality untuk Pendidikan Indonesia? 


\section{PEMBAHASAN}

\section{A. Total Quality Education}

Total Quality sering dialih bahasakan menjadi mutu terpadu (Minarti, 2011:338). Prase tersebut hampir selalu disandingkan dengan kata manajemen sehingga menjadi Manajemen Mutu Terpadu (MMT/TQM). Manajemen Mutu Terpadu adalah suatu keinginan untuk selalu mencoba mengerjakan sesuatu dengan selalu baik sejak awal. Kata total (terpadu) dalam TQM menegaskan bahwa setiap orang yang berada dalam suatu organisasi wajib untuk telibat dalam upaya peningkatan secara terus menerus. Kata manajemen disitu menegaskan bahwasannya setiap orang dalam organisasi tersebut adalah manajer untuk bidang yang ditanggung jawabi masing-masing (Sallis, 2006:74, Nata, 2012:377).

Mutu apabila dilihat dari beberapa tokoh, pertama, Philip B. Crosby berpendapat bahwa mutu berarti kesesuaian terhadap persyaratan, seperti jam tahan air, sepatu yang tahan lama, dan dokter yang ahli. la juga mengemukakan pentingnya melibatkan setiap orang dalam proses organisasi. Pendekatan Crosby merupakan proses top-down (Sallis, 2006:113-118). Kedua, W. Edwards Deming berpendapat bahwa mutu berarti pemecahan masalah untuk mencapai penyempurnaan terus-menerus, seperti penerapan Kaizen pada perusahaan Toyota dan gugus kendali mutu pada perusahaan Telkom. Pendekatan Deming merupakan proses bottom-up (Sallis, 2006: 96-98). Ketiga, Joseph M. Juran berpendapat bahwa mutu berarti kesesuaian dengan penggunaan, seperti sepatu yang dirancang untuk olahraga dan sepatu kulit yang dirancang untuk ke kantor atau ke pesta. Pendekatan Juran merupakan proses yang berorientasi pada pemenuhan harapan dari pelanggan (Sallis, 2006:107-109). Keempat, K. Ishikawa berpendapat bahwa mutu berarti kepuasan pelanggan. Dengan demikian, setiap bagian proses dalam organisasi memiliki pelanggan. Kepuasan pelanggan internal akan menyebabkan kepuasan pelanggan organisasi. Definisi mutu menurut ISO 9000:2000 adalah "derajat/tingkat karakteristik yang melekat pada produk yang mencukupi persyaratan/keinginan”. Derajat di sini berarti selalu ada peningkatan setiap saat, sedangkan karakteristik berarti hal-hal yang dimiliki produk, yang terdiri dari karakteristik fisik, perilaku, dan sensori (Wijaya, 2007:8586). Dapat ditarik kesimpulan bahwasannya Manajemen Mutu Terpadu adalah manajemen fungsional dengan pendekatan yang secara kontinu difokuskan pada peningkatan mutu, kualitas, agar LO sesuai dengan standar kualitas di 
masyarakat. Selain itu ketercapaian TQM tersebut dilihat dari indikator daya saing, kompetensi yang sesuai dengan prinsip multiple intelegences. Sehingga tidak melulu aspek kognitif yang digarap, namun aspek psikomotor dan afeksi menjadi tujuan juga.

B. Analisa Kurikulum 2013 untuk Total Quality Education di Indonesia

Perubahan adalah suatu keniscayaan (Prastowo, 2015:1). Sebuah adagium masyhur "tidak ada yang tidak akan berubah di dunia ini kecuali perubahan itu sendiri" mengisyarakan kepada kita semua untuk selalu bisa mempersiapkan diri untuk menyambut perubahan itu sendiri. Beberapa faktor seperti demokrasi, kemajuan iptek dan globalisasi menjadi aspek yang mendorong perubahan itu terjadi lebih cepat (Tilaar, 2012:13). Ketiga faktor tersebut semakin padu sehingga mengantarkan kita pada era baru yaitu era disrupsi.

Sebagai dampak dari perubahan bermasyarakat, berbangsa, bernegara di Indonesia menuntut perubahan pada aspek pendidikan nasional. Salah satu pertimbangan dan dasar pemerintah melakukan peninjauan ulang dan penyempurnaan kurikulum, yaitu dari kurikulum 2006 menjadi kurikulum 2013, adalah untuk mewujudkan masyarakat Indonesia yang mempunyai daya saing dan sanding serta penyesuaian diri dengan perubahan zaman (Majid, 2014:19, Prastowo, 2015:2).

Perubahan kurikulum 2006 ke kurikulum 2013 sangat relevan karena mutu pendidikan di Indonesia pada umumnya masih sangat rendah dan cukup jauh dari ekspektasi, serta jauh tertinggal dari negara-negara tetangga semisal Malaysia dan Singapura. Menurut laporan survei "Trends in International Math and Science" tahun 2007 yang dilakukan oleh Global Institute, menyajikan hasil bahwasannya hanya lima pesen (5\%) siswa di Indonesia mampu menyelesaikan soal dengan kategori tinggi, sedang di Korea mampu mencapai $78 \%$. Sedang menurut Programme for International Student Assessment (PISA) 2009, Indonesia termasuk 10 terbawah dari 65 negara yang ikut serta. Hampir semua siswa hanya mampu menguasai sampai dengan level 3 sedangkan pada saat yang sama negara maju mampu mencapai level empat, lima bahkan enam -setara dengan level sarjana (Mulyasa, 2013:60). Berdasarkan uraian tersebut mengantarkan penulis pada kesimpulan bahwasannya pendidikan yang ada di Indonesia tertinggal dan terbelakang. 
Terjadi dekadensi moral dalam kehidupan di masyarakat Indonesia, beberapa indikatornya seperti, tawuran pelajar, plagiarisme, korupsi, narkoba, kecurangan dalam ujian, dll. Keadaan ini tentunya memerlukan sikap tanggap pemerintah sehingga bisa mengatasi problematika ini sehingga tidak sampai mengancam eksistensi bangsa itu tersendiri. Salah satu kebijakan untuk mengatasi gejala yang telah disebutkan di atas adalah dengan penerapan kurikulum 2013.

Kurikulum 2013 diterapkan berdasarkan Permendikbud tahun 2013. Permendikbud ini datangnya disusul oleh permen-permen lain yang menjelaskan lebih dalam dan terperinci, sebut saja Permendikbud No 54 Tahun 2013 tentang Standar Kompetensi Lulusan, No 65 tentang standar Proses, No 66 tentan Standar Penilaian, No 67 tentang KD dan Struktur Kulikulum SD/MI, No 68 tentang KD dan Struktur Kulikulum SMP/MTs, No 69 tentang KD dan Struktur Kulikulum SMA/MA. Apabila dilihat maka akan sangat nampak ada penjelasan teknis dan terperinci dan berorientasi pada penjaminan mutu.

Pada standar proses, disebutkan apa saja yang harus dilakukan guru dari awal hingga akhir kegiatan belajar mengajar. Ini adalah wujud dari kontrol dengan orientasi mutu. Pada sisi ini tentunya sangat menunjang prinsip mutu itu sendiri, melihat pelaksanaan kegiatan belajar mengajar pada tataran teknis banyak lengahnya. Banyak guru yang mengajar dengan alakadarnya sehingga tidak mampu memaksimalkan kegiatan belajar tersebut sehingga berorientasi mutu. Hadirnya payung hukum ini melegitimasi pemerintah untuk mengintervensi secara langsung kegiatan belajar mengajar yang diselenggarakan oleh guru, sehingga capaian-capaian yang diharapkan bisa sesuai dengan ekspektasi pendidikan nasional.

Untuk Kompetensi Dasar, Inti mulai digarap aspek afeksi. Ini terlihat dari tema-tema yang ada pada muatan mata pelajaran. Siswa dihadapkan dengan materi yang mempunyai komposisi unik, yaitu komposisi yang mempertimbangkan aspek multiple intelegences, yang mana diorientasikan pada capaian yang tidak hanya ranah kognitif saja -seperti arus besar tujuan pendidikan selama ini di Indonesia, namun ranah afektif dan psikomotor. Pada akhirnya gejala dekadensi moral pelajar dapat diatasi sejak bengku sekolah.

Tidak habis pada materi, penilaian pun melebarkan indikatornya. Sebelum kurikulum 2013 hanya melihat ranah kognitif semata, dengan ranah afektif yang 
dilihat secara sekilas saja. Pada kurikulum 2013, ranah afektif dan psikomotor sangat ditekankan, misal saja: kejujuran, keikhlasan, kerjasama, dll. Pihak pemerintah pun telah menyediakan borang penilaian baru yang digunakan guru untuk menilai peserta didik/siswa. Sehingga pada akhirnya adanya standar ini mampu mengontrol sekaligus mendongkrak trend pendidikan yang ada di Indonesia.

\section{Gambar 1}

Aplikasi penilaian kurikulum 2013

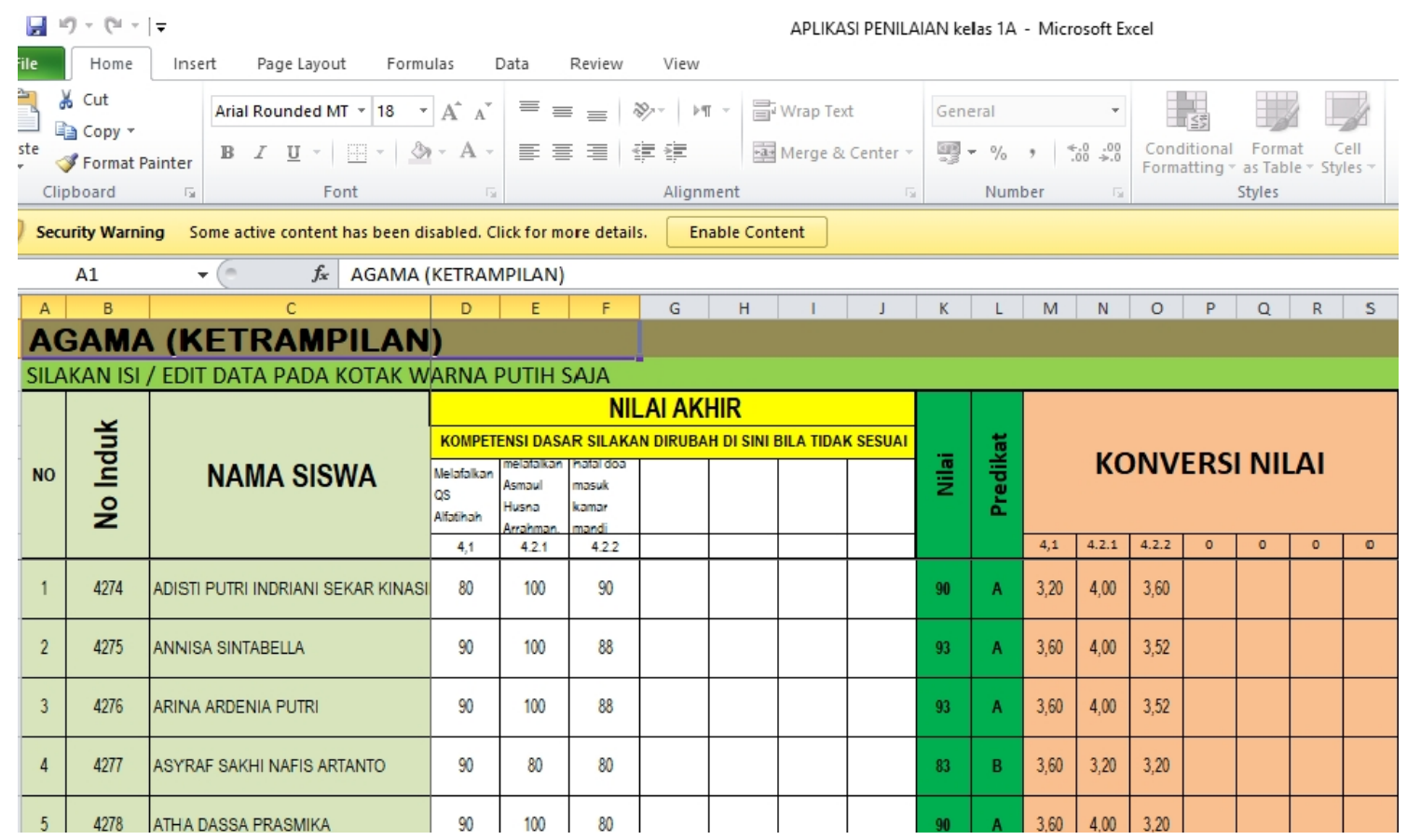

Gambar tersebut memperlihatkan aplikasi yang dirancang bangun oleh pemerintah sehingga dapat memudahkan guru dalam aspek penilaian. Apabila dilihat dari $\mathrm{KD} / \mathrm{KI}$ nya maka akan menyuguhkan diferensiasi dengan kurikulum sebelumnya. Pada kurikulum yang baru ini lebih sistematis dan dikotakkan berdasarkan ranah yang sesuai. Misal saja Kode 1 dan anak turunnya digunakan untuk aspek spiritual, kode 3 dan anak turunnya digunakan untuk mengukur ranah pengetahuan, kode 4 dan anak turunnya digunakan untuk ranah keterampilan lihat gambar diatas. Capaian-capaian lebih terinventarisir dengan rapi, segala ranah kecerdasan dapat dijangkau. Pada akhirnya LO sudah dapat diproyeksikan akan memiliki kemampuan dan ketuntasan apa, atau nomenklatur yang lebih masyhur digunakan adalah kompetensi lulusan apa yang didapat oleh peserta didik sehingga menjadi LO yang sesuai dengan kebutuhan dan urgensitas 
masyarakat. Sehingga tujuan evaluasi untuk mengukur taraf kemajuan peserta didik dalam mencapai tujuan (Hermino, 2013:172) dapat terlaksana dengan baik.

Hadirnya model baru ini tentu tidak berjalan mulus, beberapa kendala juga dihadapi. Misal saja, kesiapan guru dalam pengaplikasian borang penilaian baru ini. Ibu Guru NH belum bisa mengaplikasikan komputer sehingga input data terkendala sehingga membutuhkan bantuan guru lain untuk bisa menginput (Wawancara dengan Ibu Guru NH, Jumat 3 November 2017 Pukul 14.02). Kejadian ini tidak hanya dialami oleh Guru NH, hampir keseluruhan guru yang ada sudah berusia diatas 40 (empat puluh) tahun mengalami kendala yang sama (wawancara dengan Guru IS selaku guru yang menjadi tim ahli MGMP guru PAI kecamatan Purworejo). Pada tataran ini strategi pemerintah melalui kebijakan kurikulum 2013 menjadi manajemen konflik bagi stakeholder khususnya guru untuk mampu mengembangkan keahliannya dalam penggunaan IPTEKS (ilmu pengetahuan, teknologi dan seni) demi mendukung terlaksananya kegiatan pembelajaran. -Ada pengkondisian sehingga memungkinkan guru terpacu. Pengkodisian ini sering kali diambil oleh pengambil kebijakan, mengingat pandangan baru dari manajemen konflik yang mana memungkinkan sisi terdorongnya produktivitas. (Saeed, 2014:214-225)

Penggunaan metode saintific method menjadi salah satu faktor difenrensiasi kurikulum 2013 dengan kurikulum sebelumnya. Metode ini akan berpengaruh banyak pada ranah standar proses pembelajaran sebagaimana diatur oleh Permendikbud No 65, tahun 2013. Penggunaan metode ini memungkinkan para peserta didik untuk bisa mengamati, menanya, mencoba, menalar, mengkomunikasikan, membangun jejaring secara aktif (Mulyasa, 2015:99).

Kurikulum 2013 tidak hanya berlaku pada lembaga pendidikan dasar dan menengah. Kerangka Kualifikasi Nasional Indonesia (KKNI/IQF) apabila dilihat dari segi penetapannya yaitu adalah 2013 awal, adalah salah satu manifestasi dari semangat kurikulum 2013. Ada kesamaan dari segi spirit yang diusung, yaitu perbaikan mutu. Perbaikan mutu tersebut juga sangat relevan dengan kebutuhan masyarakat Indonesia saat ini. misal saja dilihat pada rumusan Kompentensinya (Capaian Pembelajaran / CP) yang terbagi menjadi 4, meliputi: Kompetensi Sikap, Kompetensi Pengetahuan, Kompetensi Ketrampilan Umum, Kompetensi Ketrampilan Khusus (Dirjen Dikti, 2016:20-23, Sutrisno,2016). 
Untuk mengantar pada gambaran yang kongkret, penulis suguhkan contoh rumusan kompetensi pada Ma'had Aly Krapyak Yogyakarta yang sudah mengacu pada KKNI sebagai berikut:

1. Mempunyai sikap:

a. Bertaqwa kepada Allah swt., dan mampu menunjukkan sikap religius;

b. Unggul dalam mewarisi tradisi tafaqquh fi ad-diin ulama salaf;

c. Mengintegrasikan nilai, norma, etika ulama dan akademik;

d. Menjunjung tinggi nilai kemanusiaan dalam menjalankan tugas berdasarkan agama, moral dan etika khas pesantren;

e. Berkontribusi dalam peningkatan mutu kehidupan masyarakat, berbangsa, bernegara dan peradaban berdasarkan Agama dan Pancasila;

f. Berperan sebagai warga negara yang bangga dan cinta tanah air, memiliki nasionalisme serta rasa tanggung jawab pada negara dan bangsa;

g. Menghargai keanekaragaman budaya, pandangan, agama, dan kepercayaan, serta pendapat atau temuan orisinil orang lain;

h. Bekerja dan memiliki kepekaan sosial serta kepedulian terhadap masyarakat, lingkungan dan pondok pesantren;

i. Taat hukum dan disiplin dalam kehidupan bermasyarakat dan bernegara;

j. Menunjukkan sikap bertanggung jawab atas pekerjaan di bidang fiqh dan ushul figh secara mandiri dari menjauhkan dari plagiarisme;

k. Mempunyai ketulusan, komitmen dan kesungguhan hati untuk membina umat rahmatan lil alamin.

2. Keterampilan umum:

a. Mampu menerapkan pemikiran logis, kritis, sistematis dan inovatif dalam konteks pengembangan dan implementasi fiqh dengan memperhatikan nilai humaniora;

b. Mampu menunjukkan kerja bermutu dan terukur;

c. Mampu mengkaji implementasi pengembangan atau implementasi ilmu pengetahuan dan teknologi yang memperhatikan dan menetapkan nilai humaniora sesuai kaidah, tata cara, dan etika fiqh dan ushul fiqh dalam rangka menghasilkan, gagasan dan solusi; 
d. Mampu menyusun deskripsi hasil kajian tersebut di atas dalam bentuk mudzakkirah atau laporan tugas akhir dan mengunggahnya dalam laman Ma'had Aly;

e. Mampu mengambil keputusan secara tepat dalam konteks penyelesaian masalah di bidang fiqh berdasarkan hasil analisa data dengan metoda yang tepat;

f. Mampu memelihara dan mengembangkan jaringan kerja dengan pembimbing, kolga, sejawat baik di dalam maupun di luar lembaganya;

g. Mempunyai sikap tanggung jawab akan profesinya, kreatif, inovatif dan menghindarkan dari sikap plagiasi;

h. Unggul dalam bermasyarakat dalam kerangka pembinaan umat.

3. Pengetahuan:

a. Memiliki pemahaman akidah Islam yang kuat dan mampu menanamkan dan meneguhkannya pada diri sendiri dan masyarakat;

b. Memahami wawasan ke-Indonesiaan secara komprehensif;

c. Menguasai figh dan ushul fiqh dari tingkat dasar hingga Ahli secara komprehensif holistik, dan universal, yang meliputi bidang IImu ushul, ilmu fiqh, fiqh ibadah, fiqh muamalah, fiqh munakahah, fiqh jinayah, fiqh peradilan, fiqh kontemporer, dan fiqh perbandingan;

d. Menguasai kitab kuning bukan sebatas produk ijtihad, namun juga memahami jalan pikiran dan wawasan ulama melalui karya besar mereka;

e. Mampu menganalisa dan mensintesa produk-produk fiqh klasik dan mengaktualisasikannya sesuai dengan perkembangan zaman;

f. Menguasai metode riset dan kajian pustaka;

g. Memahami bidang keilmuan yang berhubungan dan berkesinambungan, meliputi maqashid asy-syari'ah, qawa'id fiqh, tarikh tasyri', hadist ahkam, tafsir ayat ahkam, ulumul qur'an, ilmu hadits;

4. Keterampilan khusus

a. Memiliki keterampilan dalam membaca, memahami dan menguasai kitab kuning secara umum, fiqh dan ushul fiqh secara khusus sebagai khazanah khas lembaga tingkat tinggi keagamaan;

b. Menguasai metode penggalian dan pengambilan hukum (thariq alistinbath dan al-istidlal); 
c. Mampu mengaktualisasikan figh sesuai dengan prinsip-prinsipnya (ushuluhu) dan mendesain produk figh selaras dengan kebutuhan masyarakat konteks nusantara pada zamannya.

d. Mampu menyelesaikan masalah-masalah fiqhiyah kontemporer melalui penguasaan materi dan prinsip-prinsip figh seusai dengan pengembangan maqasid as-syari'ah.

e. Mampu mensyi'arkan Islam rahmatan lil 'alamin melalui pemanfaatan teknologi informasi dan seni secara efisien dan beretika.

Segi keterampilan umum dan sikap sudah dirumuskan oleh dikti, prodi hanya diberikan keluasaan untuk mengembangkan dengan mengacu pada karakteristik prodi tersendiri dengan tanpa mengurangi yang ada dari dikti. Dari uraian tersebut dapat ditarik pada pemahaman bahwasannya Kurikulum yang berangkat dari spirit 2013 mengacu kepada perbaikan mutu dari LO itu sendiri baik dari aspek sikap/psikomotor, pengetahuan/kognitif, keterampilan umum/afektif, keterampilan khusus/afektif yang berorientasi pada kompetensi.

\section{KESIMPULAN}

Pendidikan pada masa ini terus mengalami perubahan seiring dengan perubahan zaman. Perubahan pendidikan dilangsungkan untuk menyelaraskan dengan kebutuhan masyarakat, terlebih tujuan pendidikan itu sendiri untuk memaksimalkan potensi masyarakat sehingga mampu berhasil hidup di dunia dan di akhirat. Secara politis, melalui pendidikan, pemerintah mengontrol output-nya sehingga mampu bersaing baik di level nasional maupun internasional. Selain itu, pemerintah mengkontrol muatannya sehingga bisa selaras dengan tujuan pendidikan nasional, serta menjaga paradigma warganya agar tetap menjadi warga negara yang mampu menunjukkan loyalitasnya yang tercermin pada kompetensi sikap. Pemerintah melalui Kemendikbud melakukan kontrol akan mutu LO satuan pendidikan dengan memberlakukan kurikulum 2013. Indikator yang ada pada kurikulum 2013 yang meliputi 8 standar pendidikan yang tertuang dalam UU Sisdiknas dan ditahqiq oleh Permendikbud 2013 mempertegas bahwasannya kurikulum 2013 tidak lain sebagai instrumen pemerintah untuk mengkontrol mutu pendidikan yang beorientasi jaminan mutu. Selain itu hadirnya kurikulum 2013 ditujukan untuk menjawab persoalan di masyarakat semisal dekadensi moral, sehingga permasalahan moralitas pada grassroot dan internalisasi setiap insan tidak menjadi bom waktu masalah bagi level di 
atasnya, dan pada akhirnya masalah pada pemerintah seperti disorientasi bangsa. Hadirnya kurikulum 2013 tidak berjalan mulus, dan masih ada kendala seperti guru yang kurang cepat beradaptasi. Wal akhir, mengutip pandangan Dunn, bahwasannya hadirnya kebijakan seyogyanya tidak hanya menjadi policy semata namun juga ada aspek wisdom-nya. Hadirnya kurikulum 2013 tidak melulu pada kebijakan pemerintah saja, namun ada kearifan yang terkadung melalui spirit pemecahan permasalahan pendidikan tersimbol melalui relevansi dan penekanan kompetensi sikap.

\section{DAFTAR PUSTAKA}

Amtu, Onisimus. 2013. Manajemen Pendidikan di Era Otonomi Daerah. Bandung: Alfabeta.

Foucault, Michel. Power/Knowledge:Selected Interviews anda Other Writings. New York: Pantheon Books

Hermino, Agustinus. 2013. Asesmen Kebutuhan Organisasi Persekolahan. Jakarta: Kompas Gramedia.

Irianto, Agus. 2011. Pendidikan Sebagai Investasi dalam Pembangunan Suatu Bangsa. Jakarta: Kencana.

Machali, Imam dan Ara Hidayat. 2016. The Hand Book of Education Management. Jakarta: Predanamedia Grup.

Majid, Abdul. 2014. Pembelajaran Tematik Terpadu. Bandung: Rosdakarya.

Minarti, Sri. 2011. Manajemen Sekolah: Mengelola Lembaga Pendidikan Secara Mandiri. Jogjakarta:Ar-Ruzz Media.

Mulyasa, E. 2013. Pengambangan dan Implementasi Kurikulum 2013. Bandung: Rosdakarya.

2015. Guru dalam Implemenasi Kurikulum 2013. Bandung: Rosdakarya, cet II

Nata, Abuddin. 2012 Manajemen Pendidikan: Mengatasi Kelemahan Pendidikan Islam di Indonesia. Jakarta: Prenamedia Grup cet V

Panduan Praktis Penyusunan Kurikulum Pendidikan Tinggi 2016, Ristekdikti.

Prastowo, Andi. 2015. Menyusun Rencana Pelaksanaan Pembelajaran (RPP)

Tematik Terpadu: Implementasi Kurikulum 2013 untuk SD/MI. Jakarta: Prenamedia.

Ramayulis. 2015. Filsafat Pendidikan Islam: Analisis Filosofis Sistem Pendidikan Islam. Jakarta: Kalam Mulia. 
Saeed, Tahir. 2014. Leadership styles: Relationship with Management Conflict Pakistan: IJCMA Vol. 25, No. 3, diakses dari www.emeraldinsight.com/10444068.htm pada 12 Mei 2017

Sallis, Edward. 2006. Total Quality Management in Education. Jogjakarta: IRCi-SoD, cet II

Sutrisno. 2016. Desain Kurikulum Perguruan Tinggi Mengacu pada Kerangka Kualifikasi Nasional Indonesia. Bandung: Rosdakarya.

Tilaar, H.A.R. 2012. Perubahan Sosial dan Pendidikan: Pengantar Pedagogik Transformatif untuk Indonesia. Jakarta: Rinekacipta.

Wijaya, David. Implementasi Manajemen Mutu Terpadu dalam Penyelenggaraan Pendidikan di Sekolah, Jurnal Pendidikan Penabur - No.10/Tahun ke-7/Juni 2007 